\title{
Pattern of bacterial infections in children with sickle cell anemia- Indian Scenario
}

\author{
Dipty Jain (Professor \& Head of Dept. Paediatrics, GMCH, Nagpur), Neelam Gote \\ (IGGMCH, Nagpur), Pitush Raut
}

Background: Sickle cell anaemia patients are prone for infections. There is marked geographic variation in pattern of bacterial infection in these patients. India caters large population of sickle cell anaemia and data regarding pattern of bacteraemia is lacking. Hence this study was carried out with objective of identifying the bacterial organisms causing infection in children with sickle cell anaemia with febrile episodes.

Methods: Study of 468 children up to 18 years of age with sickle cell anaemia with febrile episode was done attending our hospital. Blood Cultures were sent of all patients admitted with febrile episode before administration of antibiotics.

Results- 138 episodes of bacteraemia were reported in these patients of which most were in 0-9 years age group (122/360). Almost $37.82 \%(177 / 468)$ patients were between 3 to 5 years. Most common organism isolated was staphylococcus aureus which was in 68/138 patients ( $49.27 \%$ ). The bacteria most frequently cultured from blood of the enrolled patients differ in age group like staphylococcus aureus for $76.92 \%$ of bacteraemia in patients 10-14 yr. Out of 138 blood culture positive patients, $74(53.62 \%)$ were febrile only without focus of infection. Co-morbidities like acute painful crisis $(26.71 \%, 125 / 468)$, severe anemia $(8.97 \%, 42 / 468)$ and sequestration crisis $(3.2 \%, 15 / 468)$ were commonly found in patients with positive blood culture. 4 deaths were due to Staphylococcal septicaemia.
Conclusion-Bacterial infection is a common cause of fever in patients with sickle cell anaemia. There is variation in bacterial isolate and we found Staphylococcus aureus as the most common organism. Empirical use of antibiotics for infections in Sickle cell disease should include anti Staphylococcal agents. There is need for similar type of study to be carried out in different region of India as morbidity and mortality rate due to infection are common in these patients

Table: Foci of infections in patients with respect to type of bacterial isolates

\begin{tabular}{|c|c|c|c|c|c|c|c|c|c|}
\hline Diagnosis & $\begin{array}{c}\text { Staph.a } \\
\text { ureus }\end{array}$ & $\begin{array}{c}\text { S.pne } \\
\text { umoni } \\
\text { ae }\end{array}$ & $\begin{array}{c}\text { Salmo- } \\
\text { nella }\end{array}$ & $\begin{array}{c}\text { Klebsi } \\
\text { e-lla }\end{array}$ & E.coli & $\begin{array}{c}\text { Entero } \\
\text {-cocci }\end{array}$ & $\begin{array}{c}\text { Pseud } \\
\text { o- } \\
\text { monas }\end{array}$ & $\begin{array}{c}\text { Non } \\
\text { fermen } \\
\text { ters \& } \\
\text { others }\end{array}$ & $\begin{array}{c}\text { Number } \\
\text { of } \\
\text { isolates } \\
(\mathrm{N}=138)\end{array}$ \\
\hline Pneumonia & $6(75)$ & - & - & $2(25)$ & - & - & - & - & $8(5.8)$ \\
\hline $\begin{array}{c}\text { Osteomyeliti } \\
\text { s }\end{array}$ & $1(10)$ & $1(10)$ & $2(20)$ & $4(40)$ & $2(20)$ & - & - & - & $10(7.24)$ \\
\hline $\begin{array}{c}\text { Splenic } \\
\text { abscess }\end{array}$ & $5(38.46)$ & $1(7.69)$ & $3(23.07)$ & $1(7.69)$ & - & - & $1(7.69)$ & $2(15.38)$ & $13(9.42)$ \\
\hline $\begin{array}{c}\text { Urinary } \\
\text { Tract } \\
\text { Infection }\end{array}$ & - & - & - & - & $5(100)$ & - & - & - & $5(3.62)$ \\
\hline Enteritis & - & - & $1(100)$ & - & - & - & - & - & $1(0.72)$ \\
\hline Febrile Only & $48(64.86)$ & $1(1.35)$ & $11(14.86)$ & $6(8.10)$ & $3(4.05)$ & $1(1.35)$ & $1(1.35)$ & $3(4.05)$ & $74(53.6$ \\
$2)$
\end{tabular}

\begin{tabular}{|c|c|c|c|c|c|c|c|}
\hline Age & $\begin{array}{c}\text { S. } \\
\text { Pneumoniae }\end{array}$ & $\begin{array}{c}\text { Staph. } \\
\text { Aureus }\end{array}$ & Salmonella & Klebsiella & E.coli & Others & Total \\
\hline $0-2$ & $1(7.14)$ & $4(28.57)$ & - & $4(28.57)$ & $1(28.57)$ & $4(7.14)$ & 14 \\
\hline $3-5$ & $2(3.23)$ & $33(61.29)$ & $12(19.35)$ & $7(11.29)$ & $4(6.45)$ & $4(6.45)$ & 62 \\
\hline $6-9$ & $\cdot$ & $21(45.65)$ & $4(8.7)$ & $7(15.22)$ & $6(13.04)$ & $8(17.39)$ & 46 \\
\hline $10-14$ & - & $10(76.92)$ & - & - & $1(7.69)$ & $2(15.38)$ & 13 \\
\hline$>15$ & - & - & $1(33.33)$ & $1(33.33)$ & - & $1(33.33)$ & 3 \\
\hline Total & 3 & 68 & 17 & 19 & 12 & 19 & 138 \\
\hline
\end{tabular}

Referrences:

Serjeant GR.Mortality from Sickle cell disease in Africa, Editorial, BMJ Feb 26 2005; 330:432-3.

Mohanty D, Mukherjee MB. Sickle cell disease in India. Curr Opin Hematol 2002 Mar; 9(2): 117-22.

Bansil NH, Kim TY, Tieu L et al. Incidence of serious bacterial infections in 